\title{
Effect of Sargassum wightii on Growth, Carcass and Serum Qualities of Broiler Chickens
}

\section{Athis Kumar $\mathrm{K}^{*}$ \\ Sivanthi Athithanar College, India}

*Corresponding author: Athis Kumar K, Sivanthi Athithanar College, Pillaiyarpuram, Kanyakumari District, Tamilnadu, India, Tel: 9874561330; Email: athiskumar@gmail.com

\section{Research Article}

Volume 3 Issue 2

Received Date: March 28, 2018

Published Date: May 08, 2018

\section{Abstract}

The basic feed supplemented with Sargassum powder (1\%, 2\%, 3\% and 4\%) provided more amount of essential amino acids, long chain fatty acids and minerals necessary for the growth of poultry than the basic feed. The growth promoting ability of Sargassum increased from $1 \%$ to $2 \%$ and then there was steady state, which is reflected in the weight gain, feed intake, feed conversion rate, carcass qualities and serum parameters of poultry. Sargassum powder had increased the growth to gain about $1265 \mathrm{~g}$ more weight compared to the control and the supplementing effect was the maximum at $2 \%$ Sargassum powder. The feed intake per bird increased from $4647 \mathrm{~g}$ at $1 \%$ Sargassum powder to $4813 \mathrm{~g}$ at $4 \%$ Sargassum powder while it was 3042g in the control group. The feed conversion rate increased from 51.5 to 51.8 instead of $33.9 \%$ in the control. Sargassum treatment increased the liver weight from $2.26 \%$ to $2.30 \%$, the heart weight from $0.53 \%-0,45 \%$, the gizzard from $1.76 \%$ to $1.83 \%$, the intestinal weight from 210.2 to $226.18 \%$, the leg proportion from $3.77 \%$ to $4.57 \%$, the breast weight from $28.26 \%$ to $30.27 \%$, the thigh weight from $13.37 \%$ to $14.68 \%$, the drumstick from $14.16 \%$ to $15.28 \%$ and the dressing from $70.32 \%$ to $81.12 \%$. The maximum supplementary effect was noted at $1 \%$ and $2 \%$ of the Sargassum powder. Dietary treatment of broiler chicks with Sargassum powder significantly $(\mathrm{P}<0.05)$ decreased plasma cholesterol and globulin while increased the total serum protein, albumin, calcium, phosphorus and triglyceride compared to control. The 1\% Sargassum gave 1.8 fold profits while 2\%, 3\% and 4\% Sargassum powder gave 1.95 fold profit compared to the control. Meat qualities of chicks fed with $1 \%$ and $2 \%$ Sargassum were superior to the meat of poultry fed only with the basic feed.

Keywords: Sargassum wightii; Macroscopic marine; Proteins; Vitamins 


\section{Open Access Journal of Veterinary Science \& Research}

\section{Introduction}

In recent years poultry industry has made available some feed formulations, vitamin supplements, vaccines and drugs with which the problems of under nutrition and disease outbreaks can now be managed productively. Even though such products are relatively cheap and indispensable components for poultry production units, many growers in the rural and urban parts of India cannot grow domestic fowls profitably because of low productivity and inferior basic feeds. There has been an increasing trend towards using natural feed additives to improve the performance, increase the dietary protein, energy utilization and to maintain health of birds [1]. Perusals of available literatures make it clear that dietary supplements such as probiotics, herbal powders and algal products have been put in use in the poultry ration for enhancing the growth and reproductive attributes and innate immunity to provide adequate protection to fowls. Sargassum wightii is one of the dietary supplements that have increased the growth and reproductive capabilities of fowl, shrimps, ducks and mice.

The brown seaweed $S$. wightii is a macroscopic marine alga found attached to rocky bottom of shallow coastal waters of Tamilnadu and many parts of Asia, which has been used as animal feed, food ingredients, fertilizer, medicines and raw materials [2]. This marine alga is a good source of minerals, vitamins $\left(A, B_{1}, B_{2}, C, D\right.$ and $\left.E\right)$, proteins, essential amino acids, fats, fatty acids, polysaccharides, fibers and flavanoids $[3,4]$ and its protein and lipid qualities are acceptable for humans and veterinary animals as it contains relatively high proportion of essential amino acids and unsaturated fatty acids [5]. In addition, it contains some bioactive compounds [6,7] responsible for its antiviral, anti-fungal, antioxidant, anti-inflammatory, antiallergenic, antithrombic, anti-carcinogenic, hepatoprotective and cytotoxic activities $[8,9]$ due to the presence of long-chain fatty acids [10], polyphenols [11,12], saponins [13], alkaloids, sterols [13,14], flavonoids and fucoidan [15]. The unsaturated fatty acids, especially PUFAs, increase the growth and development of many fishes and animals [16-18] and at the same time decrease the levels of the expression of cytokines necessary for shifting the function of lymphocytes from the cells mediated response to antibody-mediated response. Essential amino acids present in the seaweed make it a highly valuable protein in the food [19].

Dietary supplementation of $S$. wightii has enhanced the weight gain of mice [15], tiger shrim [20], ducks [21], poultry [22] and pigeon [23]. In poultry, dietary supplementation of $S$. wightii has increased the feed conversion rate and weight gain [21]. As this algal powder is rich in acceptable proteins, it has been recommended as a dietary supplement for cattle in China, Thailand, Korea, Japan, Indonesia and Philippines [24]. The present study was undertaken to analyze the suitability of the dried powder of $S$. wightii for using as a dietary supplement to White Leghorn broiler chickens under South Indian conditions.

\section{Materials and Methods}

\section{Preparation of Sargassum powder}

Specimens of S. wightii (Phaeophyceae) were collected from the coastal village Leepuram near Kanyakumari (Lat 9o11' N; Long79o $24^{\prime} \mathrm{E}$ ) of Tamilnadu and brought to the laboratory. They were washed repeatedly with tap water for 3 times to remove dust particles, sand and epiphytic microalgae. The whole plants were dried under shade, and then sun dried and ground into Sargassum powder. This powder was then stored in a refrigerator.

\section{Chemical Analysis of Sargassum Powder}

The protein content of Sargassum powder was estimated using the Biurrette method described by Raymont, et al. (1964) [25]. The lipid was extracted using chloroform methanol mixture as a solvent and estimated by using the method described by Folch, et al. (1956) [26]. The method described in the AOAC (1995) [27] was followed for the quantification of minerals in Sargassum powder. A $0.2 \mathrm{~g}$ of oven dried Sargassum powder was taken in a dry conical flask and treated with $10 \mathrm{ml}$ of diacid mixture (2:5 of Nitric acid and Perchloric acid). The content of conical flask was allowed to stand for a few hours for cold digestion. After that, the conical flask was kept on a hot plate to digest the contents under the influence of temperature. The digested content was filtered through a Whatman No.40 filter paper to get a filtrate. The filtrate was suitably diluted and fed into ICP Perkin Elmer Mayer Optical Emission Spectrophotometer (Optima $2100 \mathrm{DV}$ ) as per the procedure given in the Users' Manual for analyzing the amount of $\mathrm{Mg}, \mathrm{Cu}, \mathrm{Mn}, \mathrm{Fe}$ and $\mathrm{Zn}$ present in the filtrate. $\mathrm{Na}, \mathrm{K}, \mathrm{I}$ and $\mathrm{Ca}$ were analyzed with Flame Photometer. For the estimation of methionine, cystine and lysine contents, one gram of Sargassum powder was hydrolyzed with $6 \mathrm{~N}$ hydrochloric acid in evacuated sealed tube for 24 hours at $110^{\circ} \mathrm{C}$ and the hydrolyzed sample was analyzed with Waters PicoTag HPLC Amino acid Analysis System (Column: Pico-Tag amino acid analysis column, $3.9(150 \mathrm{~mm})$; detector: Waters 2489 Dual $\lambda$ absorbance detector). 


\section{Open Access Journal of Veterinary Science \& Research}

\section{Experimental Design}

This experiment was conducted in the Animal House Sivanthi Athithanar College, Pillaiyar Puram, Kanyakumari District, Tamilnadu, South India- from September 2017 to January 20018. 100 one-day unsexed broiler chicks (White Leghorns; Suguna Chickens) were purchased from a commercial hatchery and assigned at random into five experimental groups each had four replicates of five chicks; each group was kept in an open wire mesh-sided poultry house. The pens $\left(\mathrm{lm}^{2}\right)$ inside the house were prepared using wire mesh partitioning. Light was provided 24 hours in a form of natural light during the day and artificial during night.

Five experimental feeds were formulated to meet the nutrient requirements of broiler chicks according to NRC, (1994) [28]. The basic feed was formulated with sorghum (65g), groundnut cake $(13 \mathrm{~g})$, seasam cake $(15 \mathrm{~g})$, super concentrate $(5 \mathrm{~g}$; containing crude protein $40 \%$, ME 2000 $\mathrm{Kcal} / \mathrm{kg}$, crude fiber $3 \%$; calcium $8 \%$, lysine $12 \%$, Methionine 3\% and available phosphorus 8\%), shell powder (1g) and salt $(0.15 \mathrm{~g})$. The basic feed was considered as control and the other four diets was formulated with the basic feed having surgassum powder at the rate of $1 \%, 2 \%, 3 \%$ and $4 \%$ respectively. Feed and water were provided ad libitum. Chicks were vaccinated against Gumboro disease at 9 days of age and against Newcastle disease at 22 days of age. Soluble multivitamins compounds (Vimeral), and antibiotic (Colidat), were given to chicks before and after three days of the vaccination in order to guard against stress.

\section{Laboratory Tests}

Each chick was weighed weekly and feed intake was determined at the time of weighing. Mean body weight gain and feed conversion ratio (FCR) were calculated weekly. Blood samples were collected from the wing of birds before slaughter in heparinized tubes. Blood serum was separated by centrifugation at $3000 \mathrm{rpm}$ for $15 \mathrm{~min}$, and plasma obtained was stored at $-20^{\circ} \mathrm{C}$ until analysis. Plasma total protein, albumin, total lipids, total cholesterol, creatine and triglycerides were determined using spectrophotometry. On the $121^{\text {st }}$ day, the chicks were fasted overnight except from water. One chick from each replicate was randomly selected, individually weighed and slaughtered then scaled in hot water, feather plucked manually then washed and drained, eviscerated and individual organs (the liver, heart, gizzard and legs) were separately weighed.

\section{Carcass Analysis}

The carcasses were chilled at $4^{\circ} \mathrm{C}$ for 24 hours and cut into two halves. The left side was divided into the commercial cuts (breast, thigh and drumstick), each of which was weighed individually, deboned and the meat was frozen for panel taste. The meat was cut into small pieces, wrapped individually in aluminum foil and roasted at $190^{\circ} \mathrm{C}$ for 70 minutes with average internal temperature of $88^{\circ} \mathrm{C}$ and served warm to 10 well-trained taste panels to score color, flavor, tenderness and juiciness of meat [29].

\section{Statistical analysis}

Data obtained from this experiment was subjected to one-way ANOVA, using SPSS (1997) [30] computer software. The significant differences among the means of different dietary treatments were analyzed with the Duncan multiple range test [31].

\section{Results}

Chemical analysis according to the NRC (1994) [28] shows that a 100 gram of the basic feed contains crude proteins $(16.47 \mathrm{~g})$, crude fats $(3.61 \mathrm{~g})$, metabolic energy (2315.7 Kcal), calcium (1149mg), phosphorus (562mg), sodium (160 mg), copper $(0.42 \mathrm{mg})$, iodine $(0.1 \mathrm{mg})$, zinc $(2.53 \mathrm{mg})$, manganese $(2.73 \mathrm{mg})$, methionine $(280 \mathrm{mg})$, cystine (260mg), lysine (362 mg), arginine (120 mg), tryptophan (183 $\mathrm{mg})$, glycine (323 $\mathrm{mg})$, histidine (121 $\mathrm{mg}$ ), leucine (340 $\mathrm{mg}$ ), isoleucine (282mg), phenylalanine (348 mg), tyrosine (247 mg), threonine (187 $\mathrm{mg}$ ) and valine (248mg) (Tables 1 \& 2). The basic feed supplemented with Sargassum powder had relatively higher amount of all the above said nutrients than the basic feed used in the experiment. Further, the concentration of these nutrients increased with increase in the dosage of Sargassum power from 1\% to 4\% added to the basic feed. Vitamin concentration remains the same in all these feed formulations.

\begin{tabular}{|c|c|c|c|c|c|}
\hline Constituents of diet* & $\begin{array}{c}\text { Basal feed } \\
\text { (Control) }\end{array}$ & $\begin{array}{c}\text { Basal feed + 1\% } \\
\text { S.wightii }\end{array}$ & $\begin{array}{c}\text { Basal feed + 2\% } \\
\text { S.wightii }\end{array}$ & $\begin{array}{c}\text { Basal feed +3\% } \\
\text { S.wightii }\end{array}$ & $\begin{array}{c}\text { Basal feed + 4\% } \\
\text { S.wightii }\end{array}$ \\
\hline Crude protein (g) & 16.47 & 16.54 & 16.61 & 16.68 & 19.75 \\
\hline Crude fibers (g) & 5.21 & 5.26 & 5.27 & 5.32 & 5.39 \\
\hline Fats (g) & 3.61 & 3.62 & 3.63 & 3.64 & 3.65 \\
\hline
\end{tabular}

Athis Kumar K. Effect of Sargassum wightii on Growth, Carcass and Serum Qualities of Broiler Chickens. Vet Sci Res 2018, 3(2): 000156. 


\section{Open Access Journal of Veterinary Science \& Research}

\begin{tabular}{|c|c|c|c|c|c|}
\hline ME (Kcal/Kg) & 2315.7 & 2316 & 2316.3 & 2316.6 & 2316.8 \\
\hline Calcium (mg) & 1149 & 1149.16 & 1149.32 & 1149.48 & 1149.62 \\
\hline Phosphorus (mg) & 562 & 575 & 584 & 591 & 599 \\
\hline Sodium (mg) & 160 & 160.69 & 161.36 & 162.07 & 162.76 \\
\hline Zinc (mg) & 2.53 & 2.6 & 2.68 & 2.76 & 2.84 \\
\hline Manganese (mg) & 2.73 & 2.77 & 2.81 & 2.85 & 2.89 \\
\hline Iodine (mg) & 0.1 & 0.115 & 0.13 & 0.145 & 0.16 \\
\hline Copper (mg) & 0.42 & 0.46 & 0.5 & 0.54 & 0.56 \\
\hline Methionine (mg) & 280 & 317 & 354 & 391 & 428 \\
\hline Cystine (mg) & 260 & 285 & 310 & 335 & 360 \\
\hline Lysine (mg) & 362 & 408 & 454 & 500 & 546 \\
\hline Arginine (mg) & 120 & 124.6 & 129.2 & 133.8 & 138.4 \\
\hline Tryptophan (mg) & 183 & 213 & 243 & 273 & 303 \\
\hline Glycine (mg) & 323 & 326.1 & 329.2 & 332.3 & 338.4 \\
\hline Histidine (mg) & 121 & 125.1 & 129.2 & 133.3 & 137.4 \\
\hline Leucine (mg) & 340 & 345.5 & 351 & 356.5 & 362 \\
\hline Isoleucine (mg) & 282 & 286.8 & 291.6 & 296.4 & 301.2 \\
\hline Phenylalanine (mg) & 348 & 354.1 & 360.2 & 366.3 & 372.4 \\
\hline Tyrosine (mg) & 247 & 250.9 & 254.8 & 258.7 & 262.3 \\
\hline Threnonine (mg) & 187 & 194.3 & 202.8 & 210.7 & 218.6 \\
\hline Valine (mg) & 214 & 219 & 224 & 229 & 233 \\
\hline Vitamins** & Constant & Constant & Constant & Constant & Constant \\
\hline
\end{tabular}

Table 1: Levels of different dietary components in the basal feed and Sargassum supplemented test feed (100g each).

* Calculated according to NRC (1994)

**Vitamins: vit. A $2500 \mathrm{I} . \mathrm{U} / \mathrm{Kg}$; D3 $2500 \mathrm{I.U} / \mathrm{Kg}$; E $25 \mathrm{mg} / \mathrm{Kg}$; C $400 \mathrm{mg} / \mathrm{Kg}$; B2 $100 \mathrm{mg} / \mathrm{Kg}$ folic acid $30 \mathrm{mg} / \mathrm{Kg}$, choline $1000 \mathrm{mg} / \mathrm{Kg}$.

\begin{tabular}{|c|c|c|c|c|c|}
\hline Growth attribute & $\begin{array}{c}\text { Basal feed } \\
\text { (Control) }\end{array}$ & $\begin{array}{c}\text { Basal feed + } \\
\mathbf{1 \% S . w i g h t i i}\end{array}$ & $\begin{array}{c}\text { Basal feed + } \\
\mathbf{2 \% S . w i g h t i i}\end{array}$ & $\begin{array}{c}\text { Basal feed + } \\
\mathbf{3 \% S . w i g h t i i}\end{array}$ & $\begin{array}{c}\text { Basal feed + } \\
\mathbf{4 \%} \text { S.wightii }\end{array}$ \\
\hline $\begin{array}{c}\text { Initial weight (g/ } \\
\text { bird }\end{array}$ & $148^{\mathrm{a}}$ & $148.25^{\mathrm{a}}$ & $148.25^{\mathrm{a}}$ & $149.0^{\mathrm{a}}$ & $148.25^{\mathrm{a}}$ \\
\hline $\begin{array}{c}\text { Final weight (g/ } \\
\text { bird) }\end{array}$ & $1363.50^{\mathrm{a}}$ & $2560^{\mathrm{b}}$ & $2628.5^{\mathrm{a}}$ & $2628.50^{\mathrm{a}}$ & $2628.50^{\mathrm{a}}$ \\
\hline $\begin{array}{c}\text { Weight gain } \\
\text { (g/bird) }\end{array}$ & $1215.5^{\mathrm{a}}$ & $2411.75^{\mathrm{b}}$ & $2480.25^{\mathrm{a}}$ & $2479.5^{\mathrm{b}}$ & $2480.25^{\mathrm{a}}$ \\
\hline $\begin{array}{c}\text { Feed intake } \\
\text { (g/bird) }\end{array}$ & $3042^{\mathrm{a}}$ & $4647^{\mathrm{b}}$ & $4813^{\mathrm{b}}$ & $4811^{\mathrm{b}}$ & $4811^{\mathrm{b}}$ \\
\hline $\begin{array}{c}\text { Feed conversion } \\
\text { rate (\%) }\end{array}$ & $33.9^{\mathrm{a}}$ & $51.8^{\mathrm{b}}$ & $51.7^{\mathrm{b}}$ & $51.5^{\mathrm{b}}$ & $51.5^{\mathrm{b}}$ \\
\hline
\end{tabular}

Table 2: Growth attributes of poultry in response to dietary supplementation of Sargassum powder.

Figures after \pm represent standard deviation; ${ }^{\mathrm{a}} \mathrm{p}<0.05 ; \mathrm{b} \mathrm{p}>0.025$

Growth performance of chickens fed with Sargassum powder was significantly $(\mathrm{p}<0.05)$ higher than that in the control group (Table 2). The initial weight was $148 \mathrm{~g} /$ chicks and the final weight increased from $2560 \mathrm{~g}$ at 
$1 \%$ Sargassum powder to $2628 \mathrm{~g}$ at $4 \%$ Sargassum powder instead of $1363 \mathrm{~g}$ in the control. Sargassum powder had increased the growth to gain about $1265 \mathrm{~g}$ more weight compared to the control and the supplementing effect was the maximum at $2 \%$ Sargassum powder. The feed intake per bird increased from $4647 \mathrm{~g}$ at 1\% Sargassum powder to $4813 \mathrm{~g}$ at $4 \%$ Sargassum powder while it was $3042 \mathrm{~g}$ in the control group. The feed intake increased from the $1 \%$ to $2 \%$ of Sargassum powder and then there was a stationary phase. The statistical significance was $\mathrm{p}<0.05$. Diet containing 2\% Sargassum powder showed the heaviest body weight ( $p>0.05)$ compared to the tested groups, while those fed on control diet recorded significantly $(p<0.05)$ the lowest weight. The feed conversion rate increased from 51.5 to 51.8 instead of $33.9 \%$ in the control; the maximum effect was observed at $1 \%$ Sargassum powder. The statistical significance was ( $\mathrm{p}>0.05$ ).

\begin{tabular}{|c|c|c|c|c|c|}
\hline Carcass traits & $\begin{array}{c}\text { Basal feed } \\
\text { (Control) }\end{array}$ & $\begin{array}{c}\text { Basal feed + 1\% } \\
\text { S.wightii }\end{array}$ & $\begin{array}{c}\text { Basal feed + 2\% } \\
\text { S.wightii }\end{array}$ & $\begin{array}{c}\text { Basal feed + 3\% } \\
\text { S.wightii }\end{array}$ & $\begin{array}{c}\text { Basal feed + 4\% } \\
\text { S.wightii }\end{array}$ \\
\hline Live weight (g) & $1363.50^{\mathrm{a}}$ & $2560^{\mathrm{b}}$ & $2628.5^{\mathrm{a}}$ & $2628.50^{\mathrm{a}}$ & $2628.50^{\mathrm{a}}$ \\
\hline Liver weight (\%) & $2.26^{\mathrm{a}}$ & $2.29^{\mathrm{b}}$ & $2.30^{\mathrm{b}}$ & $2.30^{\mathrm{b}}$ & $2.29^{\mathrm{b}}$ \\
\hline Heart (\%) & $0.53^{\mathrm{a}}$ & $0.542^{\mathrm{b}}$ & $0.545^{\mathrm{b}}$ & $0.544^{\mathrm{a}}$ & $0.543^{\mathrm{a}}$ \\
\hline Gizzard (\%) & $1.76^{\mathrm{a}}$ & $1.81^{\mathrm{b}}$ & $1.83^{\mathrm{a}}$ & $1.82^{\mathrm{b}}$ & $1.82^{\mathrm{a}}$ \\
\hline Intestine (g) & $210.2^{\mathrm{a}}$ & $222.32^{\mathrm{a}}$ & $226.18^{\mathrm{b}}$ & $226.20^{\mathrm{b}}$ & $226.19^{\mathrm{b}}$ \\
\hline Legs (g) & $3.77^{\mathrm{a}}$ & $4.30^{\mathrm{b}}$ & $4.57^{\mathrm{b}}$ & $4.58^{\mathrm{a}}$ & $4.57^{\mathrm{b}}$ \\
\hline Breast (\%) & $28.26^{\mathrm{a}}$ & $29.31^{\mathrm{b}}$ & $30.27^{\mathrm{a}}$ & $29.26^{\mathrm{b}}$ & $29.26^{\mathrm{b}}$ \\
\hline Thigh (\%) & $13.37^{\mathrm{a}}$ & $14.58^{\mathrm{a}}$ & $14.67^{\mathrm{b}}$ & $14.68^{\mathrm{b}}$ & $14.66^{\mathrm{b}}$ \\
\hline Drumstick (\%) & $14.16^{\mathrm{a}}$ & $15.23^{\mathrm{b}}$ & $15.26^{\mathrm{a}}$ & $15.27^{\mathrm{a}}$ & $15.28^{\mathrm{b}}$ \\
\hline Wing (\%) & $11.24^{\mathrm{a}}$ & $10.72^{\mathrm{a}}$ & $10.64^{\mathrm{b}}$ & $10.62^{\mathrm{b}}$ & $10.61^{\mathrm{b}}$ \\
\hline Dressing (\%) & $70.32^{\mathrm{a}}$ & $79.21^{\mathrm{b}}$ & $81.12^{\mathrm{b}}$ & $79.32^{\mathrm{b}}$ & $79.33^{\mathrm{b}}$ \\
\hline
\end{tabular}

Table 3: Variation in the carcass traits of poultry in response to dietary supplementation of Sargassum powder. Figures after \pm represent standard deviation; ${ }^{\mathrm{a}} \mathrm{p}<0.05$; ${ }^{\mathrm{b}} \mathrm{p}>0.05$

Carcass traits of chicken fed with Sargassum powder were significantly $(p<0.05)$ different from those of chickens fed only with the basal feed (Table 3). Live weight of a chick was 1363.50 in the control and it was in the range of $2560-2628 \mathrm{~g}$ in chicken fed with Sargassum powder, of which the maximum effect was shown at $2 \%$ of the supplement. Sargassum treatment increased the liver weight from $2.26 \%$ to $2.30 \%$, the hear weight from $0.53 \%-0,45 \%$, the gizzard from $1.76 \%$ to $1.83 \%$, the intestinal weight from 210.2 to $226.18 \%$, the leg proportion from $3.77 \%$ to $4.57 \%$, the breast weight from $28.26 \%$ to $30.27 \%$, the thigh weight from $13.37 \%$ to $14.68 \%$, the drumstick from $14.16 \%$ to $15.28 \%$ and the dressing from $70.32 \%$ to $81.12 \%$. The maximum supplementary effect was noted at $1 \%$ and $2 \%$ of the Sargassum powder. The statistical significance was (P> $0.05)$. Wing weight decreased significantly $(p>0.05)$ from $11.24 \%$ to $10.61 \%$.
Dietary treatment of broiler chicks with Sargassum powder significantly $(\mathrm{P}<0.05)$ decreased plasma cholesterol and globulin while increased the total serum protein, albumin, calcium, phosphorus and triglyceride compared to control (Tables $3 \&$ 4). In birds fed with Sargassum, serum glucose level increased from 206.2 to $208.7 \mathrm{~g} / \mathrm{dl}$ instead of $204.2 \mathrm{mg} / \mathrm{dL}$; total serum proteins slightly increased to 2.34 from $2.2 \mathrm{mg} / \mathrm{dL}$ (control); albumin level increased from 1.7 to $1.9 \mathrm{mg} / \mathrm{dL}$ instead of $1.1 \mathrm{mg} / \mathrm{dl}$ in the control; triglycerides increased from $96.4 \mathrm{mg}$ to $113.2 \mathrm{mg} / \mathrm{dL}$ instead of 80.3 in control; the serum phosphate level increased from $7.6 \mathrm{mg}$ to $8.6 \mathrm{mg} / \mathrm{dL}$ instead of $5.5 \mathrm{mg} / \mathrm{dl}$ (control); and the calcium content increased from $11.3 \mathrm{mg}$ to $12.2 \mathrm{mg} / \mathrm{dL}$ instead of $10.4 \mathrm{mg} / \mathrm{dl}$ in the control. Statistical significance in these cases was $\mathrm{p}<0.05$. Sargassum powder reduced the cholesterol level from 122.1 (control) to $96.7 \mathrm{mg} / \mathrm{dL}$ and the globulin level from $1.1 \mathrm{mg} / \mathrm{dl}$ (control) to $0.41 \mathrm{mg} / \mathrm{dL}$. 


\section{Open Access Journal of Veterinary Science \& Research}

\begin{tabular}{|c|c|c|c|c|c|}
\hline Serum parameter & $\begin{array}{c}\text { Basal feed } \\
\text { (Control) }\end{array}$ & $\begin{array}{c}\text { Basal feed + 1\% } \\
\text { S.wightii }\end{array}$ & $\begin{array}{c}\text { Basal feed + 2\% } \\
\text { S.wightii }\end{array}$ & $\begin{array}{c}\text { Basal feed + 3\% } \\
\text { S.wightii }\end{array}$ & $\begin{array}{c}\text { Basal feed + 4\% } \\
\text { S.wightii }\end{array}$ \\
\hline Glucose (mg/dL) & $204.2^{\mathrm{a}}$ & $206.1^{\mathrm{a}}$ & $208.2^{\mathrm{a}}$ & $208.6^{\mathrm{b}}$ & $208.7^{\mathrm{b}}$ \\
\hline $\begin{array}{c}\text { Total serum proteins } \\
(\mathrm{mg} / \mathrm{dL})\end{array}$ & $2.2^{\mathrm{a}}$ & $2.31^{\mathrm{b}}$ & $2.33^{\mathrm{a}}$ & $2.34^{\mathrm{b}}$ & $2.31^{\mathrm{b}}$ \\
\hline Albumins (mg/dL) & $1.1^{\mathrm{a}}$ & $1.7^{\mathrm{a}}$ & $1.9^{\mathrm{b}}$ & $1.92^{\mathrm{a}}$ & $1.9^{\mathrm{a}}$ \\
\hline Globulins (mg/dL) & $1.1^{\mathrm{a}}$ & $0.6^{\mathrm{a}}$ & $0.43^{\mathrm{a}}$ & $0.42^{\mathrm{b}}$ & $0.41^{\mathrm{b}}$ \\
\hline Cholesterol (mg/dL) & $122.1^{\mathrm{a}}$ & $102.2^{\mathrm{b}}$ & $97.6^{\mathrm{a}}$ & $96.7^{\mathrm{b}}$ & $96.7^{\mathrm{a}}$ \\
\hline Triglycerides (mg/dL) & $80.3^{\mathrm{a}}$ & $96.4^{\mathrm{b}}$ & $112.2^{\mathrm{b}}$ & $113.1^{\mathrm{a}}$ & $113.2^{\mathrm{b}}$ \\
\hline Phosphate (mg/dL) & $5.5^{\mathrm{a}}$ & $7.6^{\mathrm{b}}$ & $8.3^{\mathrm{b}}$ & $8.5^{\mathrm{b}}$ & $8.6^{\mathrm{a}}$ \\
\hline Calcium (mg/dL) & $10.4^{\mathrm{a}}$ & $11.3^{\mathrm{b}}$ & $12.1^{\mathrm{b}}$ & $12.2^{\mathrm{b}}$ & $12.2^{\mathrm{b}}$ \\
\hline
\end{tabular}

Table 4: Serum parameters of poultry in response to dietary supplementation of Sargassum powder.

Figures after \pm represent standard deviation; ${ }^{\text {a }} \mathrm{p}<0.05$; ${ }^{\mathrm{b}} \mathrm{p}>0.05$.

Live weight of poultry revealed that $1 \%$ Sargassum gave 1.8 fold profits while $2 \%, 3 \%$ and $4 \%$ Sargassum powder gave 1.95 fold profit compared to the control.
Chicks fed with $2 \%$ Sargassum gave the highest profit followed by those fed on diet containing $1 \%$ of this supplement (Table 5).

\begin{tabular}{|c|c|c|c|c|c|}
\hline Meat parameter & Basal feed (Control) & $\begin{array}{l}\text { Basal feed + } \\
1 \% \text { S.wightii }\end{array}$ & $\begin{array}{l}\text { Basal feed + } \\
2 \% \text { S.wightii }\end{array}$ & $\begin{array}{l}\text { Basal feed + } \\
3 \% \text { S.wightii }\end{array}$ & $\begin{array}{l}\text { Basal feed + } \\
4 \% \text { S. wightii }\end{array}$ \\
\hline Colour & Moderate & Good & Good & Good & Good \\
\hline Flavour & Moderate & Good & Good & Medium & Medium \\
\hline Tenderness & Moderate & Good & Good & Medium & Low \\
\hline Juiciness & Moderate & Good & Good & Low & Low \\
\hline Taste & Moderate & Good & Good & Low & Low \\
\hline
\end{tabular}

Table 5: Likely qualities of meat from the consumers.*

${ }^{*}$ Good $=<7$ score; Moderate $=<5$ score; Medium $=<3$ score; Low $=>2$ score.

In the consumer point of view, colour is good in all the Sargassum treatments but flavor was medium at 3and $4 \%$ of Sargassum powder. Tenderness was good at $1 \%$ and $2 \%$ of this supplement. Juiciness and taste were good at $1 \%$ and $2 \%$ of the dietary supplement but low at higher dosages (3\% and $4 \%)$. The average meat quality scores were above moderate level at the $1 \%$ and $2 \%$ Sargassum powders.

\section{Discussion}

Nutritional components in the feed and supplements are the determinants of the growth, maturation and reproduction of birds [32]. Banergee has stated that the daily diet of a broiler chick should contain crude protein $(16 \mathrm{~g})$, crude fiber $(7.0 \mathrm{~g})$, crude fat $(3.5 \mathrm{~g})$, methionine (450mg), cystine (200 mg), lysine (600 mg), arginine (500 $\mathrm{mg}$ ), tryptophan (130 mg), glycine (600 $\mathrm{mg}$ ), histidine (200mg), leucine (750 mg), isoleucine (400mg), phenylalanine (640 $\mathrm{mg}$ ), tyrosine $(400 \mathrm{mg})$, threonine (400 mg) and valine (450 mg), phosphorus (600 mg), calcium (1.0 g), Zinc $(25 \mathrm{mg})$, iodine $(0.35 \mathrm{mg})$, sodium $(0.15 \mathrm{mg})$, copper $(0.2 \mathrm{mg})$, manganese $(5.0 \mathrm{mg})$, iron (trace amount), vitamin $\mathrm{A}$ (2000 IU), Vitamin $\mathrm{D}_{3}$ (200 IU), Vitamin $B_{1}(0.30 \mathrm{mg})$, Vitamin $B_{2}(0.30 \mathrm{mg})$, Vitamin $B_{6}$ $(0.30 \mathrm{mg})$, Vitamin $B_{12}(1.0 \mathrm{mg})$, biotin $(6 \mu \mathrm{g})$, choline $(70$ $\mathrm{mg})$, folic acid $(0.10 \mathrm{mg})$, niacin $(3.0 \mathrm{mg})$ and panthothenic acid (10 mg). The basic feed used in our experiment could provide adequate amount of crude proteins, crude fiber, crude fat, metabolic energy, phosphorus, calcium, iodine, sodium, copper, vitamin $A$, vitamin $D_{3}$, Vitamin $B_{1}$, Vitamin $B_{2}$, Vitamin $B_{6}$, Vitamin $B_{12}$, biotin, choline, folic acid, niacin and panthothenic acid to pigeons, but it had inadequate amount of zinc, manganese, methionine, 
cystine and lysine, which have to be supplied in yet other form for effective growth of pigeons. Since Sargassum powder had Na $(690 \mu \mathrm{g} / \mathrm{g}), \mathrm{K}(182 \mu \mathrm{g} / \mathrm{g}), \mathrm{P}(45 \mathrm{mg} / \mathrm{g})$, Ca $(80 \mu \mathrm{g} / \mathrm{g}), \mathrm{Mg}(5892 \mu \mathrm{g} / \mathrm{g}), \mathrm{Mn}(21.3 \mu \mathrm{g} / \mathrm{g}), \mathrm{Zn}(73.4 \mu \mathrm{g} /$ g), $\mathrm{Cu}(39.5 \mu \mathrm{g} / \mathrm{g}), \mathrm{Fe}(256 \mu \mathrm{g} / \mathrm{g})$, Al $(182 \mu \mathrm{g} / \mathrm{g})$, Co $(1.2$ $\mu \mathrm{g} / \mathrm{g})$, methionine $(280 \mathrm{mg} / \mathrm{g})$, cystine $(260 \mathrm{mg} / \mathrm{g})$ and lysine $(367 \mathrm{mg} / \mathrm{g})$, it could also enrich the diet with all these minerals and enabled the diet to have adequate quantity of manganese and zinc.

Essential amino acids present in the seaweed make it a highly valuable protein in the food of animals and man [19,33-36]. Sargassum powder contains aspartic acid $(1.80 \%)$, glutamic acid $(1.15 \%)$, serine $(0.54 \%)$, glycine $(0.45 \%)$, histidine $(0.45 \%)$, arginine $(0.60 \%)$, threonine $(0.71 \%)$, alanine $(0.44 \%)$, proline $(0.38 \%)$, tyrosine $(0.49 \%)$, valine $(0.50 \%)$, methionine $(0.37 \%)$, cystine $(0.25 \%)$, isoleucine $(0.55 \%)$, leucine $(0.55 \%)$, phenilealanine $(0.63 \%)$, tryptophan $(0.21 \%)$ and lysine (0.50 [36], of which methionine, cystine and lysine are the essential amino acids for poultry [37]. Powder of S.wightii contains fatty acids like caproic acid, caprylic acid, capric acid, lauric acid, tridecylic acid, myristic acid, pentadecyclic acid, palmitoleic acid, margaric acid, stearic acid, oleic acid, linoleic acid, $\gamma$-linolenic acid, $\alpha$ - linolenic acid, arachidic acid, dihomo- $\gamma$-linolenic acid, arachidonic acid, heneicosylic acid, eicosapentaenoic acid, behenic acid, docosahexaenoic acid and lignoceric acid $[38,10]$, of which unsaturated fatty acids (UFAs) like myristic acid, palmitoleic acid, oleic acid, $\gamma$-linoleic acid, $\alpha$-linolenic acid, arachidonic acid and eicosapentaenoic acid are found in larger proportions. Since these UFAs are essential fatty acids for animals, they increase the growth and development of many fishes and animals [16-18] and at the same time decrease the levels of the expression of cytokines necessary for shifting the function of lymphocytes from the cells mediated response to antibody-mediated response. It is therefore concluded that Sargassum powder could improve the dietary values of the basic diet and its effect was increasing with increase in the dosage from $1 \%$ to $4 \%$ added to the basic diet.

Growth of chicken has been reflected in the live weight of body weight and carcass qualities. As has been reported by Mariey, et al. (2013) [39], who had demonstrated that yeast supplementation has increased the body weight of pigeons, Sargasssum powder had increased the body weight of broiler chickens due to its dietary supplementing property that is associated with rich minerals, and vitamins [6,7], long-chain fatty acids [10], essential amino acids [11-13] sterols [14] and fucoidan. The rate of increase in the body weight of fowls and veterinary animals is determined by feed intake and subsequent conversion of the feed into various metabolites and body tissues [40-44]. The feed intake of birds generally varies greatly depending on the genetic race of bird, age group and the type of feed provided to them $[45,46]$. However, it is further altered by nutritional supplements added to the feed [47]. Dietary supplementation of Sargassum extract had enhanced the feed intake and body weight gain in poultry, ducks [21], pigeon [23] and aquaculture fishes and shrimps [20]. In this line of investigation, these results agree with the findings of El-Sayed (1982) [48], El-Deek, et al., (1987) [22], Gu, et al., (1998) [49], Wong and Cheung (2001) [50], Sim, et al., (2004) [51], EL-Deek, et al., (2011), Breikaa (1993) [21], Felix, et al. (2004) [20] and Athis Kumar (2017) [23]. 2\% Sargassum powder is enough in the daily diet to produce the maximum weight gain in poultry since it can promote the maximum food conversion rate. As natural feed additives, Sargassum improved the diet palatability to intake more food compared to the control and enhanced its digestion followed by intestinal absorption as noted by Michael and Kumawat, (2003) and Alloui, et al., (2012) .

The high level of feed conversion is reflected in the meat qualities and carcass traits of poultry [51]. As a consequence, live weight, liver weight, heart (\%), Gizzard (\%), Intestine weight, legs (\%), breast (\%), thigh (\%), drumstick (\%)and dressing (\%) are increased and the wing (\%) is slightly decreased while feeding the chickens with Sargassum powder. In this context, the present study coincides with the findings of Guo, et al., (2004) [49], Alloui, et al., (2012), Mukhtar, et al., (2013) [51,52], Amal, et al., (2013) [53] and Tariq Mamoun, et al. (2014) [54] who reported improvement carcass qualities of broiler feed with lemon grass oil, Halfa bar essential oil and fenugreek powder respectively.

Since Sargassum is a good source of minerals, vitamins, proteins, essential amino acids [5], it might have improved the protein synthetic machinery to produce more amounts of proteins in poultry as reported El-Sayed (1982) [48], Gu, et al. (1998) [49], Sim, et al. (2004) [51], and Breikaa (1993) [21]. Therefore, total serum protein and albumins are produced in large proportions. Sargassum powder reduces cholesterol synthesis and as a consequence triglycerides are increased in the blood of poultry due to the presence of certain chemical constituents that promote faster metabolism of triglycerides [14,11,13,10,23]. The hypocholesterolemic effect of Sargassum powder may also be due to its active ingredients such as saponins, hemicelluloses, mucilage, tannin and pectin, which help lower blood LDL- 


\section{Open Access Journal of Veterinary Science \& Research}

cholesterol levels by inhibiting bile salts $[51,52,54]$. Phosphate and calcium enriched by Sargassum might have increased their concentration in the serum as confirmed by reports of Mukhtar, et al., (2013)[51,52].

The meat quality score is always superior to the meat produced from the control group but taste is slightly changed at 3\% and $4 \%$ of Sargassum powder because of over accumulation of minerals that are not assimilated for the growth of chicken. However, all these qualities of meat obtained from poultry fed with Sargassum are above the acceptable level. These results coincide with the findings of Mukhtar, et al., (2013) [51,52].

\section{Conclusion}

The present investigation confirms that Sargassum powder has increased the weight gain of poultry partly due to its minerals, essential amino acids and long chain fatty acids necessary for growth and partly due to enhancement of food-intake and food conversion rate of chicks. $2 \%$ of Sargassum powder added to the diet has the maximum growth promoting activity as well as body weight gain of fowls. Live weight of poultry is reflected in the ratio of carcasses and meat quality, which are the deciding factor for the profits to the growers. The growers can get 1.9 folds more income while chickens are fed with $2 \%$ Sargassum powder along with the basic diet. Since Sargassum has reduced the globulin content and cholesterol in the serum, it is presumed that cholesterol content of meat is also reduced simultaneously. As low cholesterol level is likely to avoid heat problems, and as the meat score is good for human consumption, this is superior to meat of poultry maintained only with the basal feed.

\section{References}

1. Abdel-Aal ESM, Attia RS (1993) Characterization of black cumin (Nigella sativa) seeds Proteins. Alex Sci Exch 14: 483-496.

2. Levering T, Hoppe HA, Schmid OJ (1969) Marine Algae. A survey of research and Utilization. Granm be Gruyter \& Co., Hamburg, pp: 1-421.

3. Lahaye M (1991) Marine algae as a source of dietary fibers: Determination of soluble and insoluble dietary fiber contents in some 'sea vegetable'. J Sci Food Agric 54(4): 587-594.
4. Darcy-Vrillon B (1993) Nutritional aspects of the developing use of marine macroalgae for the human food industry. Int J Food Sci Nutr 44: 523-535.

5. Thillaikkannu Thinakaran, Mohan Balamurugan, Kathiresan Sivakumar (2012) Screening of phytochemical constituents qualitatively and quantitatively certain seaweeds from Gulf of Mannar biosphere reserve. IRJP 3(7): 261-265.

6. Meenakshi S, Manicka GD, Tamilmozhi S, Arumugam M, Balasubramanian T (2009) Total flavonoid and in vitro antioxidant activity of two seaweeds of Rameshwaram Coast. Global J Pharmcol 3(2): 59-62.

7. Antonisamy JM, Essakimuthu P, Narayanan J, Anantham B, Tharmaraj RJJM, et al. (2012) Phytochemical characterization of brown seaweed Sargassum wightii. Asian Pac J Trop Dis 2(1): S109S113.

8. Jiang H, Zhan WQ Liu X, Jiang SX (2008) Antioxidant activities of extracts and flavonoid compounds from Oxytropis falcate Bunge. Nat Prod Res 22(18): 16501656.

9. Jeyaraman Amutha, Iswarya Devi, Gopalswamy Sathiya Balan, Kasiviswanathan Periyanayagam (2013) Pharmacognostical study and phytochemical evaluation of brown seaweed Sargassum wightii. Journal of Coastal Life Medicine 1(3): 199-204.

10. Visakh Prabhakar R, Anandan Aneesh TP, Jayasree NB, Sreejith V Nair, Halima OA (2011) Fatty acid composition of Sargassum wightii and Amphiroa anceps collected from the Mandapam coast Tamil Nadu, India. J Chem Pharm Res 3(1): 210-216.

11. Chandini SK, Ganesan P, Bhaskar N (2008) In vitro antioxidant activities of three selected brown seaweeds of India. Food Chem 107(2): 707-713.

12. Ganesan P, Chandini SK, Bhaskar N (2008) Antioxidant properties of methanol extract and its solvent fractions obtained from selected Indian red seaweeds. Bioresour Technol 99(8): 2717-2723.

13. Rajasulochana $\mathrm{P}$, Dhamotharan $\mathrm{R}$, Krishnamoorthy $\mathrm{P}$ (2009) Primary phytochemical analysis of Kappaphycus sp. J Am Sci 5(2): 91-96.

14. Sanchez-Machado DI, Lopez-Hernandez J, PaseiroLosada P, Lopez-Cervantes J (2004) An HPLC 


\section{Open Access Journal of Veterinary Science \& Research}

method for the quantification of sterols in edible seaweeds. Biomed Chromatogr 18(3): 183-190.

15. Yung-Choon Yoo, Woo-Jung Kim, So-Yeon Kim, SungMin Kim, Mi-Kyung Chung, et al. (2007) Immunomodulating Activity of a Fucoidan Isolated from Korean Undaria pinnatifida Sporophyll. Algae 22(4): 333-338.

16. Nordoy A (1989) Fish oils in clinical medicine. J Int Med 225(3): 145-147.

17. Estevez A, McEvoy LA, Bell JG, Sargent JR (1999) Growth, survival, lipid composition and pigmentation of turbot (Scophthalmus maximus) larvae fed liveprey enriched in arachidonic and eicosapentaenoic acids. Aquaculture 180(3-4): 321-343.

18. Evans RP, Zhu P, Parrish CC, Brown JA (2000) Lipid and amino acid metabolism during the early development of marine fish, In: Seafood in health and nutrition - transformation in fisheries and aquaculture: global perspectives, F. Shahidi (ed.), Sci. Tech Publ. Co., St. John's, Newfoundland 477-493.

19. Orr ML, Watt BK (1968) Amino acid content of foods, Home Econ. Res. Rep, ARS-USDA, U.S. Gov. Print. Off., Washington pp: 82.

20. Felix S, Robins PH, Rajeev A (2005) Immune enhancement in Indian white, shrimp by addition of seaweed. Indian Veterinary Journal 82: 1327-1328.

21. Breikaa A Mervat (1993) Nutritional and biological evaluation of marine seaweed containing diets offered as mash vs pellets in the nutrition of ducks. Fac. Of Agric. Alex. Univ. PhD Thesis.

22. El-Deek AA, Asar MA, Safaa Hamdy MA, Kosba MA, Osman M (1987) Nutritional value of marine seaweed in broiler diets. J Agric Sci Mansoura Univ 12: 707717.

23. Athis Kumar K (2017) Growth, Reproduction and Immunomodulation of Lahore Pigeons in Response to Dietary Supplementation of Lactobacillus acidophilus, Andrographis paniculata and Sargassum wightii, $\mathrm{PhD}$ Thesis Submitted to Manonmaniam Sundaranar University, Tirunelveli, pp. 290p.

24. Kolanjinathan K, Ganesh P, Saranraj P (2014) Pharmacological Importance of Seaweeds: A Review, World Journal of Fish and Marine Sciences 6 (1): 0115.
25. Raymont J, Austin EJ, Lineford E (1964) Biochemical studies on zooplankton: The Biochemical composition of Neomycis integer. J Cans Perm Emplor Mer 28(3): 354-363.

26. Folch J, Lees M, Solane Stanley GH (1957) A simple method for the isolation and purification of total lipids from animal tissues. J Biol Chem 226(1): 497509.

27. AOAC (1995) Official methods of analysis, $16^{\text {th }}$ (Edn,). Association of official analytical chemists, Washington, DC.

28. National Research Council (NRC) (1994) Nutrient Requirements of Poultry. 9 ${ }^{\text {th }}$ Rev (Edn.), National Academy Press, Washington, DC.

29. Cross HR, Moen R, Stafield MS (1978) Training and testing of judges for sensory evaluation of meat quality. Food Technology 32: 48-52.

30. SPSS (1997) SPSS user's guide statistics Version 10. Copyright SPSS Inc., USA.

31. Duncan DB (1955) Multiple range and multiple F-test. Biometrics 11(1): 1-42.

32. Levi WM (1954) The Pigeons: R.L.Company. Columba. S.C (C.F. Abed Al-Azeem, F, et al. 2006).

33. Kanazawa A, Teshima SI, Kazuo O (1979) Relationship between essential fatty acid requirements of aquatic animals and the capacity for bioconversion of linolenic acid to highly unsaturated fatty acids. Comp. Biochem. Physiol B Biochem Mol Biol 63(3): 295-298.

34. Bell MV, Henderson RJ, Sargent JR (1986) The role of polyunsaturated fatty acids in fish. Comp. Biochem Physiol B Biochem Mol Biol 83(4): 711-719.

35. Qasim R (1991) Amino acids composition of some seaweeds. Pakistan Journal of Pharmaceutical Science 4(1): 49-54.

36. Vinoj Kumar V, Kaladharan P (2007) Amino acids in the seaweeds as an alternate source of protein for animal feed. J Marine Boiol Ass India 49(1): 35-40.

37. Vogel C, Gerlach H, Loffler M (1994) Columbiformis, In: Branson W Ritchie, Greg J Harrison and Linda R. Harrison (Eds) Avian Medicine: Principles and 
Applications, Wingers Publishing Inc., Florida, 1994, pp.1200-1217.

38. Vasanthi HR, Rajamannikkam GV, Saraswathi A (2003) Fatty acid profile of some marine algae in and around the Rameshwaram coastal waters, Seaweed Res Utiln 25: 123-126.

39. Mariey YA (2013) Nutritional and Management Studies on the Pigeon: Effect of Dietary Teast Supplementation on Productive and Reproductive Performance of Pigeon. Egypt Poult Sci 33(II): 349356.

40. Goldflus F, Ariki J, Kronka SN, Sakomura VK, Moraes VMB (1997) Effects of husing density during the cold and hot season on the broiler performance. Revista da Sociedade Brasileira de Zootecnia 26(5): 948-954.

41. Shanawany MM (1988) Broiler performance under high stocking densities. Br Poult Sci 29(1): 43-52.

42. Kuan KK, Adnan S, Ramlah H (1990) Effect of increasing stocking density on performance in broilers. Pertanika 13(2): 171-175.

43. Beg MAH, Hamid A, Ahmed S (1994) The effect of stocking density on the performance of broiler chicks, Bangladesh Journal of Animal Science 23(1-2): 89-94.

44. Tangendjaja B, Yoon I (2002) Effect of yeast culture on egg production and mortality in layer hens. Poult Sci 81(1): 89-90.

45. Iscan KM, Cetin O, Tepeli C, Dere S (1996) The effect of stocking density on broiler performance. Poultry Science 51(3): 331-335.

46. Tind E, Ambrosen T (1988) Laying hen kept in cages, the effect cage shape, group-size and unit area. Poultry Abstracts 15(1-6): 40.
47. Youssef S Mervat, Mervat A Breakaa, Nazala Y Abou El-Ella, Abdalla A (2001) Performance of Gimmizah laying hens fed various levels of phosphorus and dry yeast (Saccharomyces cerevisiae). Egypt. Poult Sci J 21(IV): 977-996.

48. El-Sayed MM (1982) The polysaccarides of the brown seaweed Trubinaria murrayana. Carbohydrate Research 110: 277-282.

49. Gu HY, Liu YG, Shu ZZ (1988) Nutrient composition of marine algae and their feeding on broilers. Chinese J Anim Sci 3: 12-14.

50. Gu HY, Liu YG, Shu ZZ (1988) Nutrient composition of marine algae and their feeding on broilers. Chinese J Anim Sci 3: 12-14.

51. Mukhtar MA, Mohamed KA, Amal OA, Ahlam AH (2013a) Response of Broiler Chicks to Different Dietary Levels of Black Cumin Oil as a Natural Growth Promoter University of Bakht Alruda Scientific Journal 7: 185-190.

52. Mukhtar MA, Mohamed KA, Amal OA, Ahlam H (2013b) Response of Broiler Chicks to different Dietary Levels of Spearmint Oil (SPO) as a Natural Growth Promoter. University of Bakht Alruda Scientific Journal 6: 175-183.

53. Amal OA, Mukhtar AM, Mohamed KA, Ahlam AH (2013) Use of Half bar Essential Oil (HBO) as a Natural Growth Promoter in Broiler Nutrition. International Journal of Poultry Science 12(1): 15-18.

54. Tariq Mamoun, Mukhtar Ahmed Mukhtar, Mohamed $\mathrm{H}$ Tabidi (2014) Effect of Fenugreek Seed on the Performance, Carcass and Some Blood Attributes. Adv Res Agri Vet Sci 1(1): 6-11. 